ISSN (print): 1698-6180. ISSN (online): 1886-7995

www.ucm.es/info/estratig/journal.htm

Journal of Iberian Geology 38 (1) 2012: 225-238

http://dx.doi.org/10.5209/rev_JIGE.2012.v38.n1.39214

\title{
Active tectonics in the central and eastern Betic Cordillera through morphotectonic analysis: the case of Sierra Nevada and Sierra Alhamilla
}

\author{
Tectónica activa en la Cordillera Bética Oriental y Central \\ mediante análisis morfotectónico: el caso de Sierra Nevada y Sierra Alhamilla
}

\author{
J. M. Azañón*1,2, J. V. Pérez-Peña ${ }^{1}$ F. Giaconia², G. Booth-Rea ${ }^{1,2}$, J. M. Martínez-Martínez ${ }^{1,2}$, \\ M. J. Rodríguez-Peces ${ }^{3}$ \\ ${ }^{1}$ Departamento de Geodinámica, Campus de Fuentenueva s/n, Universidad de Granada, 18071 Granada, Spain. \\ ${ }^{2}$ Instituto Andaluz de Ciencias de la Tierra (UGR-CSIC), Granada, Spain \\ 3. Departamento de Geodinámica, Universidad Complutense de Madrid, C/ J. Antonio Novais 12, 28040 Madrid, Spain \\ *corresponding author: jazanon@ugr.es
}

Received: 11/07/2011 / Accepted: 05/03/2012

\begin{abstract}
Quaternary activity of folds and faults can be assessed by the analysis of drainage network and the evaluation of geomorphic indexes. These analyses are especially productive in semiarid areas where tectonic rates are low-to-moderate and Quaternary dating is limited. In this work, we have revisited the most relevant GIS-based methodologies used to assess tectonic activity by using morphometric analyses and we discuss the tectonic implications in two key areas of the central and eastern Betic Cordillera (Sierra Nevada and Sierra Alhamilla regions). In the Sierra Nevada area, the use of geomorphic indexes in the mountain range and in the neighboring Granada and Guadix-Baza basins suggests that all are part of the same SW-directed extensional system. The Granada basin (except in its NE border) subsided during the Late Pleistocene as it is located in the hanging wall of the extensional system. On the other hand, the Sierra Nevada mountain range, the NE border of the Granada basin and the Guadix-Baza basin are located in the active uplifted foot wall of the system. Thus, the higher fluvial incision rates in the Guadix-Baza basin can be directly correlated with the most recent uplift history of Sierra Nevada mountain range. In the Sierra Alhamilla region, a geomorphic study shows Late Pleistocene activity along the North Alhamilla Reverse Fault and the dextral transpressive South Gafarillos Fault, two segments of the Polopos Fault Zone, previously considered as an inactive fault.
\end{abstract}

Keywords: Betic Cordillera, active tectonics, drainage networks, tectonic geomorphology

Resumen

La actividad cuaternaria de pliegues y fallas puede ser estimada mediante el análisis de las redes de drenaje y el cálculo de índices geomorfológicos. Este tipo de análisis es especialmente útil en zonas semiáridas con tasas de bajas y moderadas de actividad tectónica, y con escasas dataciones cuaternarias. En este trabajo hemos hecho una revisión de los principales trabajos que utilizan 
metodologías desarrolladas con SIG para la evaluación de actividad tectónica por medio de análisis morfométricos y discutimos sus aportaciones en dos áreas claves de la Cordillera Bética central y este (Sierra Nevada y Sierra Alhamilla). En la región de Sierra Nevada, el cálculo de índices geomorfológicos tanto en la sierra como en las cuencas neógenas de Granada y Guadix-Baza pone de manifiesto que los tres son parte del mismo sistema extensional. La cuenca de Granada (excepto su borde NE) está situada sobre el bloque de techo del sistema extensional y por tanto sometida a subsidencia, mientras que Sierra Nevada, la cuenca de Guadix-Baza y el borde NE de la propia cuenca de Granada están situados en el bloque de muro del sistema, sometido a un levantamiento activo. De este modo, las altas tasas de incisión registradas en la Cuenca de Guadix-Baza tienen una correlación directa con la historia más reciente del levantamiento de Sierra Nevada. En la región de Sierra Alhamilla, un estudio geomorfológico pone de manifiesto la activación en el Pleistoceno Superior de la falla inversa del borde norte de Sierra Alhamilla y del segmento sur de la falla transpresiva dextral de Gafarillos, ambos segmentos de la falla de Polopos, la cual había sido previamente considerada como inactiva.

Palabras clave: Cordillera Bética, tectónica activa, redes de drenaje, geomorfología tectónica.

\section{Introduction}

Active tectonics is one of the fastest growing disciplines in Earth Sciences due to the recent development of new geochronological and geodetic tools which facilitate the acquisition of accurate rates (uplift rates, incision rates, erosion rates, slip rates on faults, etc.) at variable $\left(10^{3}-10^{6}\right.$ years) time-scales (e.g., Schumm et al., 2000; Burbank and Anderson, 2001; Keller and Pinter, 2002; Bull, 2007; 2009).

Tectonic geomorphology is a relatively new discipline within active tectonics. It provides valuable tools to assess tectonic activity of structures with low-to-medium deformation rates, especially when there is a lack of Quaternary dating. In the field of tectonic geomorphology and landscape evolution, the use of Geographic Information Systems (GIS) is relatively recent. The availability of Digital Elevation Models (DEM) has produced a revolution in this field. DEM have replaced old topographic maps, allowing for better and faster analysis of topographic parameters. One of the most important features of DEM is the possibility of extracting river networks with stream gradients and catchment areas.

The analysis of drainage networks is a powerful tool to detect recent tectonic activity and uplift (e.g. Ouchi, 1985; Clark et al., 2004) as river channels are very sensitive to changes in the parameters that control their shape and gradient (e.g. Whipple and Tucker, 1999; Korup, 2006). Rivers tend to develop equilibrium profiles in relative short times $\left(10^{3}-10^{6} \mathrm{yr}\right)$, and therefore, anomalies in the river network systems, once other factors as lithology or climate are discarded, are normally due to recent tectonic activity. Therefore, geomorphic indexes based on river parameters as gradient, relief, properties of watersheds, etc., can provide relevant information of the Quaternary activity of tectonic structures. The technologies that GIS provide to perform statistical analyses, as well as the great availability of high-precision DEM, have allowed the advance in the field of geomorphic indexes.
Within this methodological framework it is possible to calculate effectively traditional geomorphic indexes as well as re-formulate them in order to achieve a better morphometric analyses.

In this work we summarize some of these new GISbased methodologies that analyze drainage networks through the calculation of geomorphic indexes. We show that the application of such methodologies in areas of low-to-medium tectonic rates $(0.1-2 \mathrm{~mm} / \mathrm{yr})$, as the central and eastern Betic Cordillera, allow evaluating recent tectonic activity that otherwise would be imperceptible. We revisit some of the new geomorphic analyses carried out in two areas of the Betic Cordillera, namely the Sierra Nevada and the Sierra Alhamilla areas (Fig. 1). The first area comprises the Sierra Nevada mountain range and the Granada and Guadix-Baza Neogene basins. The new morphometric analyses suggest that the present-day relief of this area is the result of the recent tectonic activity of an extensional system involving not only Sierra Nevada mountain range, but also the Granada and Guadix-Baza Neogene to Quaternary basins. In the Sierra Alhamilla area, the use of geomorphic indices allows estimating active tectonic rates for Pleistocene structures.

\section{Summary of GIS-based methodologies for land- scape analysis}

\subsection{SLk index and SLk anomaly maps}

The original SL index was defined by Hack (1973) as:

$$
\mathrm{SL}=(\Delta \mathrm{H} / \Delta \mathrm{L}) \cdot \mathrm{L}
$$

where SL is the stream length-gradient index in a particular channel reach, $\Delta \mathrm{H} / \Delta \mathrm{L}$ is the channel slope, and $\mathrm{L}$ is the total channel length from the central point of the river reach where the SL is calculated to the highest point on the channel. The SL index highlights anomalies in river longitudinal profiles, providing criteria to evaluate and quantify these slope changes (Hack, 1973; Kel- 
Fig. 1.- General tectonic sketch of the central and eastern Betic Cordillera. The inset shows the location within the Betic Cordillera. (Gr. Basin stands for Granada basin; G-B. Basin stands for GuadixBaza basin).

Fig. 1.- Esquema tectónico general de los sectores central y oriental de la Cordillera Bética. El recuadro muestra la localización respecto de la Cordillera Bética. (Gr. Basin corresponde a Cuenca de Granada; G-B. Basin corresponde a Cuenca de Guadix-Baza).

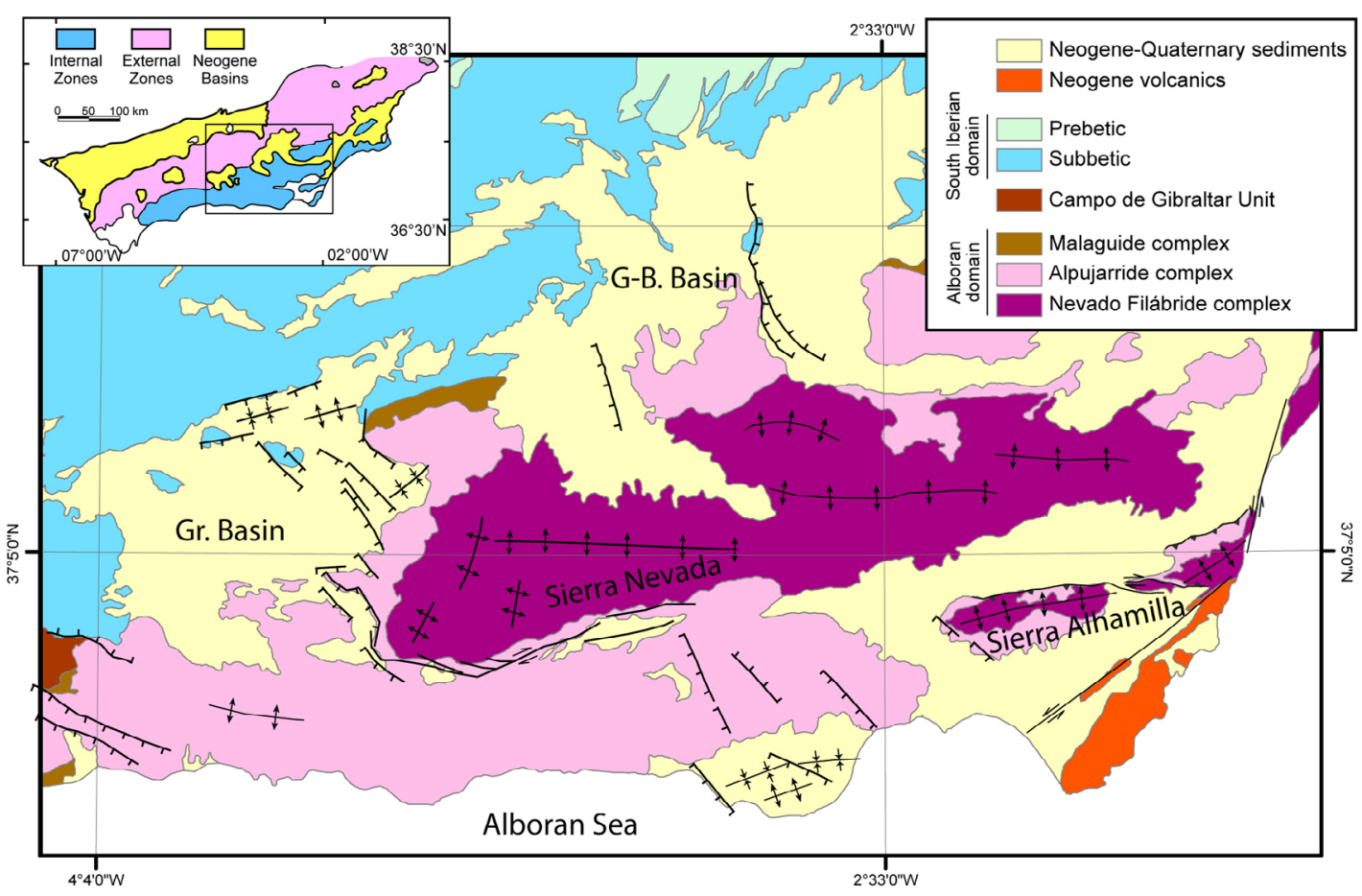

ler and Pinter, 2002; Pérez-Peña et al., 2009a).The SL index is very sensitive to changes in channel slope. These changes are mainly due to lithologic, tectonic, or climatic factors. Perez-Peña et al. (2009a) proposed a re-defined SLk index, by using the graded river gradient $(\mathrm{K})$ to normalize the SL index. These authors also proposed a new GIS-based methodology to create SLk anomaly maps by using geostatistical kriging. This methodology has been used to evaluate the activity of tectonic structures (faults and folds) in some recent studies in the Betic Cordillera with good results (Pérez-Peña et al., 2009a; Pedrera et al., 2009; Giaconia et al., 2012).

\subsection{Hypsometry analysis through GIS}

The hypsometric curve represents the distribution of area and altitude within the selected basins (Strahler, 1952). This curve is obtained by plotting the proportion of the total basin height (relative height) against the proportion of total basin area (relative area) (Strahler, 1952; Keller and Pinter, 2002; Pérez-Peña et al., 2009b). The shape of the hypsometric curve is related to the degree of dissection of the basin (e.g. its erosional stage). The hypsometric integral $(H I)$ is defined as the area below the hypsometric curve and it varies from 0 to 1 . HI values of 1 depict drainage basins in a youthful geomorphic stage and they are related with convex hypsometric curves, HI values near 0 are typical of mature basins reaching the peneplain stage and they relate with concave hypsometric curves. Perez-Peña et al. (2009c) proposed a GIS-based methodology for the analysis of the hypsometry by using local indices of spatial autocorrelation (LISA). They extracted the HI values for regular squares (not for drainage basins) and observed that the raw estimation of HI values did not present a clear view of grouped high or low values. However, when they applied Moran's I autocorrelation index and $\mathrm{Gi}^{*}$ hot-spot statistical analysis (Moran, 1950; Ord and Getis, 1995), the HI values grouped in cluster of high and low values. They proved that the clusters were closely related with the activity of tectonic structures.

\section{3. $V_{f}$ and $S_{m f}$ indexes}

Valley width to valley height ratio $\left(V_{f}\right)$ (Bull and McFadden, 1977) is a geomorphic index conceived to discriminate between $\mathrm{V}$-shaped valleys ( $V_{f}$ values close to 0 ) and U-shaped flat-floored valleys (high $V_{f}$ values). Deep V-shaped valleys are associated with linear active incision, and related to areas subjected to active tectonics, while flat-floored valleys are characteristic of sectors with less river incision and low tectonic activity (e.g. Keller and Pinter, 2002). This index has been applied to evaluate the relative degree of tectonic activity of several mountain fronts located in the eastern and central Betic Cordillera (Silva et al., 2003; GarcíaTortosa et al., 2008; Pedrera et al., 2009; Pérez-Peña et al., 2010).

Mountain-front sinuosity was defined by Bull (1977) as:

$$
\mathrm{S}_{\mathrm{mf}}=\mathrm{L}_{\mathrm{mf}} / \mathrm{L}_{\mathrm{s}}
$$


where $S_{m f}$ is the mountain front sinuosity; $L_{m f}$ is the length of the mountain front along the foot of the mountain, i.e., the topographic break in the slope, and Ls is the length of the mountain front measured along a straight line. This index has been used to evaluate the relative tectonic activity along mountain fronts (Bull and McFadden, 1977; Keller and Pinter, 2002; Silva et al., 2003; Bull, 2007; Pérez-Peña et al., 2010; Giaconia et al., 2012). In active mountain fronts, uplift will prevail over erosional processes, yielding straight fronts with low values of $S_{m f}$ Along less active fronts, erosional processes will generate irregular or sinuous fronts with high values of $S_{m f}$. Some studies have proposed that values of the $S_{m f}$ index lower than 1.4 are indicative of tectonically active fronts (Silva et al., 2003).

\subsection{Erosion analysis through GIS}

GIS technologies offer exceptional tools to analyze the erosion processes within an area. Pérez-Peña et al. (2009d) proposed a methodology to reconstruct the morphology of theGuadix-Baza basin prior to the entrenchment of the river network. The methodology proposed in their work consists of reconstructing the morphology of a glacis surface formed on top of the sedimentary sequence prior to river entrenchment. These authors used a raster Digital Elevation Model (DEM) with a 20-m resolution to isolate the pixels (cells) representing the glacis and to reconstruct its initial morphology. This reconstructed model was compared with the present-day morphology of the Guadix-Baza basin to estimate the volume of sediments eroded since the basin was captured by the Guadalquivir River system. With this methodology it is possible to obtain not only the erosion rates for the sedimentary basin, but also a view of how erosion evolved in the basin since its capture (Pérez-Peña et al., 2009d).

This methodology can be also applied to drainage basins in mountain ranges by interpolating the altitudes from present-day lateral divides of the basins (Menéndez et al., 2008). This surface is known as ridgeline surface and can be deemed as a theoretical pre-incision surface. Therefore, the altitude differences between this surface and the present-day relief can be deemed as a proxy of the erosion within the drainage basin (Menéndez et al., 2008; Pérez-Peña et al., 2010).

\section{Geological and tectonic setting.}

\subsection{The Sierra Nevada area}

The Sierra Nevada mountain range (Fig. 1) has been considered as an orogenic dome or core-complex struc- ture (Martínez-Martínez et al., 2004) exhumed since the Late Miocene in an extensional tectonic regime. The Pliocene-Quaternary tectonic evolution of this range is responsible for the formation of a large-scale open antiformal ridge coincident with the whole extent of the Sierra Nevada and coeval normal faulting. Some authors have considered this antiformal ridge as related to a blind-thrust buried under the northern E-W oriented mountain front of the Sierra Nevada (Galindo-Zaldívar et al., 2003). Normal faulting in this model is related to NNW-SSE extension sub-perpendicular to the maximum Africa-Iberia present-day shortening. Nevertheless, other authors (Martínez-Martínez et al., 2006; Pérez-Peña et al., 2010) consider that the present-day topography of the Sierra Nevada is the consequence of the interference of two orthogonal sets of Miocene-Pliocene largescale open folds trending roughly E-W and NNE-SSW. These authors interpreted the NNE-SSW fold, as well as the normal NW-SE faults of the western border of Sierra Nevada, as related to the westward migration of a rolling hinge behind the active extensional loci. These normal faults limit the Neogene-Quaternary Granada sedimentary basin, and they clearly indicate activity in QuaternaryHolocene times (Calvache and Viseras, 1997; Alfaro et al., 2001). Some authors have proposed slip rates of $0.6-0.8 \mathrm{~mm} / \mathrm{yr}$ for these normal faults in the Quaternary (Sanz de Galdeano, 1996; Keller et al., 1996). However, recent studies have proposed higher slip rates for them (Reinhardt et al., 2007). These authors dated Quaternary sediments using radiometric methods and proposed that $50 \mathrm{~m}$ of a fault-related base-level fall must have occurred in the last $21 \mathrm{ka}$.

The Sierra Nevada is bounded west and northwards by two of the largest Neogene-Quaternary basins in the central Betic Cordillera, the Granada and Guadix-Baza basins respectively (Fig. 1). These two basins have quite similar sedimentary records (Rodríguez-Fernández et al., 2012), and both changed in Quaternary times from an internal to an external drainage to the Atlantic Ocean via the Guadalquivir River (the biggest river in south Spain). Despite these similarities, the Quaternary geomorphic evolution and the present-day topography of the GuadixBaza and Granada basins are quite different. The differences are probably linked to the recent tectonics of the Sierra Nevada extensional dome. The Guadix-Baza basin's present-day topography consists of a high plateau with a mean altitude of $1000 \mathrm{~m}$, strongly dissected by the river network (Pérez-Peña et al., 2009d; García-Tortosa et al., 2011) (Fig. 1). Its Late Quaternary evolution is mostly dominated by erosional processes that followed its capture by the Guadalquivir River (Azañón et al., 2005). In contrast, the Late Quaternary evolution of the Granada 
basin is dominated by active normal faulting along its northeastern border, where the maximum relief is concentrated. The remainder of the basin has a mean altitude of $\approx 700 \mathrm{~m}$, being scarcely incised by the fluvial network (Pérez-Peña et al., 2009d).

\subsection{The Sierra Alhamilla area}

The Neogene to Quaternary sedimentary basins in the southeastern Betic Cordillera, like the Sorbas-Tabernas and the Almería-Níjar basins, initiated as extensional sedimentary depocentres formed in the hinterland of the Gibraltar orogenic arc during the middle to late Miocene (García-Dueñas et al., 1992; Martínez-Martínez and Azañón, 1997; Comas et al., 1999; Booth-Rea et al., 2005; Booth-Rea et al., 2007). However, late Miocene to present convergence between Nubia and Iberia (Dewey et al., 1989; McClusky et al., 2003; Serpelloni et al., 2007) has resulted in tectonic inversion of the extensional basins and development of folds, reverse and strike-slip fault systems including dextral and sinistral faults (Weijermars et al., 1985; Montenat and Ott d'Estevou, 1990; Comas et al., 1999; Booth-Rea et al., 2004). The most important sinistral strike-slip faults active during the latest Miocene and Quaternary are the Carboneras (Bell et al., 1997; Gràcia et al., 2006), the Alhama de Murcia (Martínez-Díaz, 2002; Masana et al., 2004), the Palomares (Bousquet, 1979; BoothRea et al., 2004), and the Terreros sinistral fault-zones (Booth-Rea et al., 2004), all of them with NNE/SSW to NE/SW trends. Dextral faults conjugate to these are not as large and show a WNW/ESE orientation, like the Gafarillos fault zone (Fig. 1, Ott d'Estevou and Montenant, 1990; Stapel et al., 1996; Barragán, 1997; Huibregtse et al., 1998; Jonk and Biermann, 2002).

Most of the Pliocene and Quaternary sedimentary cover in the eastern basins of the Betic Cordillera is related to releasing jogs of strike-slip faults (e.g. Montenat and Ott d'Estevou, 1990) or in synclines between E/W to ENE/WSW-elongated antiformal ridges, where the metamorphic basement is bounded by folded extensional detachments (Martínez-Martínez and Azañón, 1997; Martínez-Martínez et al., 2002; Booth-Rea et al., 2005). This basement is made up of several metamorphic complexes belonging to the Alboran domain, a terrain that collided with the South Iberian and Maghrebian passive margins during the Miocene, forming the Gibraltar arc and the Betic and Rif cordilleras (Balanyá and García-Dueñas, 1987; Martínez-Martínez and Azañón, 1997; Platt et al., 2003; Booth-Rea et al., 2007). The Sierra Alhamilla anticlinorium is an example of these elongated antiformal ridges where metamorphic rocks crop out, surrounded by Miocene to Quaternary sediments of the Sorbas-Tabernas and Níjar-Almería basins (Fig. 1). Most of the deformation leading to the development of the Alhamilla anticlinorium occurred during the late Miocene, being sealed by Messinian carbonates (Weijermars et al., 1985). This, for example, occurred with the Gafarillos dextral fault zone to the northeast of the Alhamilla anticlinorium (Fig. 1). Thus, most authors have considered that this dextral strike-slip system, conjugate to the NE-SW sinistral Cabrera and Palomares faults has been inactive since the Messinian (Ott d'Estevou and Montenant, 1990; Stapel et al., 1996; Huibregtse et al., 1998; Jonk and Biermann, 2002). Here we show how the use of geomorphic indexes in the Sierra Alhamilla anticlinorium area has unveiled the presence of active segments of both reverse and strike-slip faults that form the Polopos Fault Zone (PFZ) (Giaconia et al., 2012).

The main late Miocene to Quaternary tectonic structures in the Sierra Alhamilla region are the transpressive dextral-reverse Polopos Fault Zone that includes the dextral Gafarillos fault segments to the east of the ridge and their continuation towards the west as the North Alhamilla reverse fault (NARF) in the northern limb of the Alhamilla anticlinorium (Ott d'Estevou and Montenant, 1990; Stapel et al., 1996; Huibregtse et al., 1998; Jonk and Biermann, 2002). The southwestern side of the Alhamilla ridge, in the Almería-Níjar basin, PlioceneQuaternary high-angle normal faults occur with NW-SE to NNW-SSE strike (Fig. 1, Martínez-Martínez and Azañón, 1997; Marín-Lechado et al., 2005; Pedrera et al., 2006; Sanz de Galdeano et al., 2010).

\section{New geomorphic analyses}

\subsection{Morphotectonic analyses in a central Betic region: The Sierra Nevada area}

\subsubsection{Geomorphic indexes in Sierra Nevada}

The fault-bounded mountain fronts of western Sierra Nevada have been studied through the $S_{m f}$ index (Fig. $2)$. The values of this geomorphic index for western $\mathrm{Si}$ erra Nevada (Fig. 2) indicate active fronts, in which the tectonic activity prevails over the erosion forces (Martín-Rojas et al., 2001; El Hamdouni et al., 2008). PérezPeña et al. (2010) also calculated the $S_{m f}$ index for the south and northern border of Sierra Nevada, combining their values with the $V_{f}$ index. Their results indicate that the more recent uplift is concentrated along its western mountain front, where $S_{m f}$ and $V_{f}$ present the lowest values (Fig. 2). The southern mountain front of Sierra Nevada is characterized by low values of $S_{m f}$ and $V_{f}$, with 


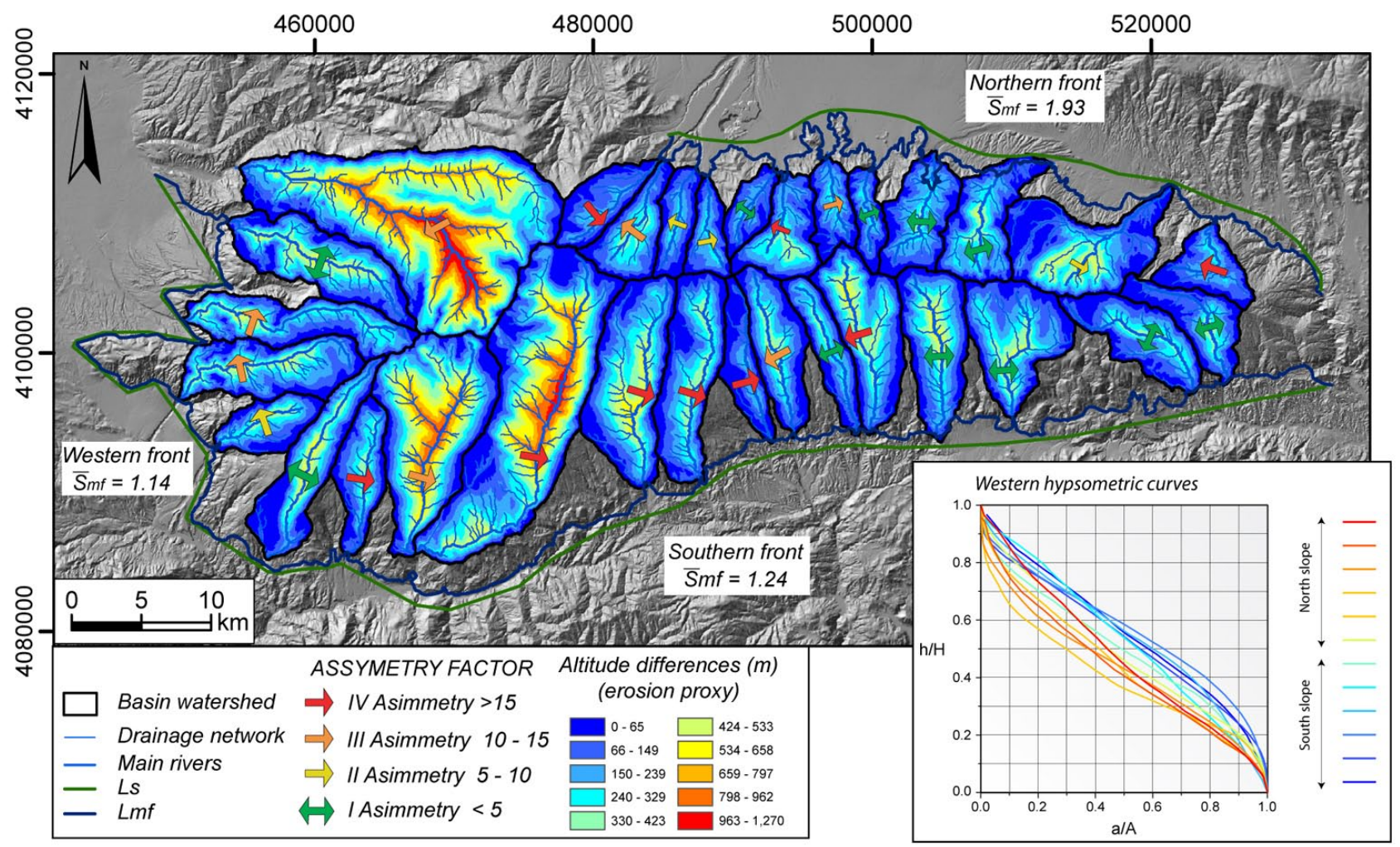

Fig. 2.- Digital elevation model (DEM) with the drainage network and the calculated geomorphic indexes in the Sierra Nevada mountain range. The arrows show the direction of basin asymmetry and the colors its magnitude (see Pérez-Peña et al., 2010 for further details). The western, southern, and northern mountain fronts are depicted. $S_{m f}$ values indicate that western and southern fronts are tectonically active whereas the northern front is inactive. Altitude differences between basin ridgeline-surfaces and present day topography show that the erosion is more prominent in the western part of the mountain range. The inset shows the differences between northern and southern hypsometric curves from the western sector of the Sierra Nevada.

Fig. 2.- Modelo digital del terreno con la red de drenaje y los índices geomorfológicos calculados en Sierra Nevada. Las flechas indican el sentido de la asimetría de las subcuencas y los colores la magnitud (ver Pérez-Peña et al., 2010 para más detalles). Se representan los frentes montañosos occidental, meridional y septentrional. Los valores de $S_{m f}$ indican que los frentes meridional y occidental son tectónicamente activos mientras que el frente norte es inactivo. Las diferencias entre la topografía actual y una superficie extrapolada a partir de las trazas de las divisorias locales muestran que la erosión es más prominente en el sector occidental de Sierra Nevada. El recuadro muestra las diferencias entre las curvas hipsométricas del sector occidental de Sierra Nevada.

$S_{m f}$ values increasing eastward. Nevertheless, the northern mountain front, which corresponds to the contact between the Guadix-Baza basin and the northern limb of the E-W antiformal ridge, has the highest $S_{m f}$ and $V_{f}$ values, thus suggesting low rates of tectonic activity, and thus pointing to an inactive northern fold limb during the Quaternary (Fig. 2).

In the same study, Perez-Peña et al. (2010) point that other geomorphic indicators, including hypsometric curves (Fig. 2), longitudinal/ridge-line river profiles, and drainage patterns, depict $\mathrm{N}-\mathrm{S}$ variations. They relate these $\mathrm{N}-\mathrm{S}$ variations as due to the fact that the local base-level is $\approx 1100 \mathrm{~m}$ in the northern mountain front of the Sierra Nevada and $\approx 600 \mathrm{~m}$ in the southern front, i.e., the southern slope streams have more erosional power than the northern ones. These differences in base-level altitudes could be the response to a differential tectonic uplift of the northern mountain front with respect to the southern one.

All the geomorphic indicators show that the western part of Sierra Nevada range is more active than the eastern part. Vazquez et al. (2011) showed, by using U/Th-He and Fission Tracks dating, a westward migration of the locus of extension in Sierra Nevada. Thus, the western sector of this range has been exhumed later than the eastern one. On the other hand, NE-SW open folds, outcropping in the western termination, are responsible of changes in the asymmetry of subbasins (Fig. 2, Pérez-Peña et al., 2010), which is a clear evidence of Pleistocene activity of these folds. Analysis of erosion in the Sierra Nevada range, which can be approximated by means of the altitude differences between ridgeline surfaces and presentday topography, is also compatible with the aforementioned geomorphic results, showing the highest volume of erosion in the western sector (Fig. 2). 


\subsubsection{Geomorphic analyses in the Granada and Guadix-Baza basins}

Through the morphometric analysis of the drainage network of the Granada and Guadix-Baza basin it is possible to have a new view of the Quaternary evolution of both basins and, consequently, of their tectonic activity. In the Granada basin (Fig. 3), there is a lack of Quaternary ages, making it difficult to evaluate the Quaternary activity of the active structures within the basin. PérezPeña et al. (2009a) studied the SLk index in the NE border of the Granada basin, and they proposed that the NW-SE normal faults presented evidences of Quaternary activity (Figs. 3 and 4). Their SLk anomaly map (Fig. 4) showed several anomalies, some of them clearly related with the Quaternary activity of the NW-SE normal faults. In the SLk anomaly map presented by these authors, the anomalies 1, 5, 3, and 4 match with the aforementioned normal fault systems. Some of them have a lithological component, but anomaly 3 in figure 4 presents high SLk values within the same materials in an area with documented present-day fault activity (Azañón et al., 2004).

The hypsometry analysis in the Granada basin reveals also the same pattern; a NE border being uplifted by the activity of the NW-SE normal fault (Pérez-Peña et al., 2009c) (Fig. 5). The use of LISA to the HI value distribution shows that the NE border of the Granada basin is affected by differential uplift related with the NW-SE normal faults, thus having a different drainage pattern system than the rest of the basin (Pérez-Peña et al., 2009c). This drainage pattern, which presents deep incised V-shaped valleys, is similar to the Guadix-Baza drainage system.

The Quaternary landscape evolution of the GuadixBaza Neogene basin is conditioned by erosional proc- esses. Pérez-Peña et al. (2009d) studied the erosion rates within this basin to elucidate its Quaternary landscape evolution. The great differences in the erosion rates obtained between the Guadix and Baza sub-basins are the consequence of three factors: the position of the capture point near the Guadix sub-basin, the greater area of the Baza sub-basin, and the Quaternary activity of the Baza fault, which affected the normal propagation of the erosion wave eastwards (See Figure 6 in Pérez-Peña et al., 2009d). The activity of the Baza fault (Alfaro et al., 2008; García-Tortosa et al., 2008, 2011) has been also corroborated by other authors through morphometric analyses. García-Tortosa et al. (2008) applied geomorphic indexes to the Baza fault and considered this fault as one of the most active faults of the Betic Cordillera. The activity of this N-S active normal fault contrasts with the absence of faults in the southern border of the basin. This border, despite being the limit with the Sierra Nevada mountain range, does not present significant tectonic activity in Quaternary times (Pérez-Peña et al., 2010).

\subsection{Morphotectonic analyses in an eastern Betic region: The Sierra Alhamilla area.}

\subsubsection{Geomorphic response to the Polopos fault zone}

Fault segmentation and fluvial terrace mapping along the Polopos fault zone have shown that both its reverse and dextral strike-slip fault segments cut Pleistocene sediments (Giaconia et al., 2012). This Quaternary to present activity is reflected by the geomorphic indexes study. The low $S_{m f}$ index values occurring in the Sierra Alhamilla northern front, especially eastwards, support the late Pleistocene activity of the North Alhamilla re-

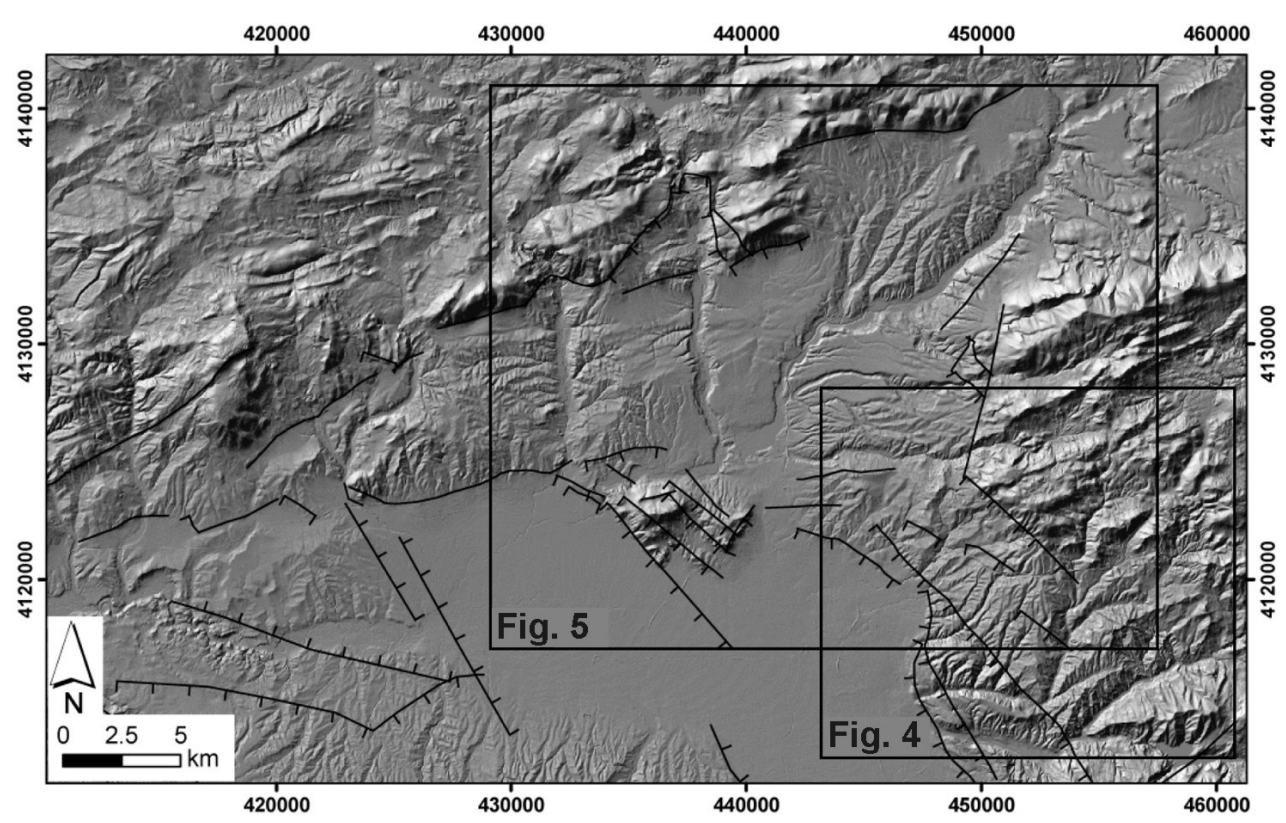

Fig. 3.- Digital elevation model (DEM) of the NE border of the Granada basin. The higher river entrenchment can be observed in the footwall of the main NW-SE normal faults.

Fig. 3.- Modelo digital del terreno del borde NE de la Cuenca de Granada. Los principales encajamientos de las partes altas de los cauces fluviales pueden observarse en el bloque de muro de las principales fallas normales NW-SE. 


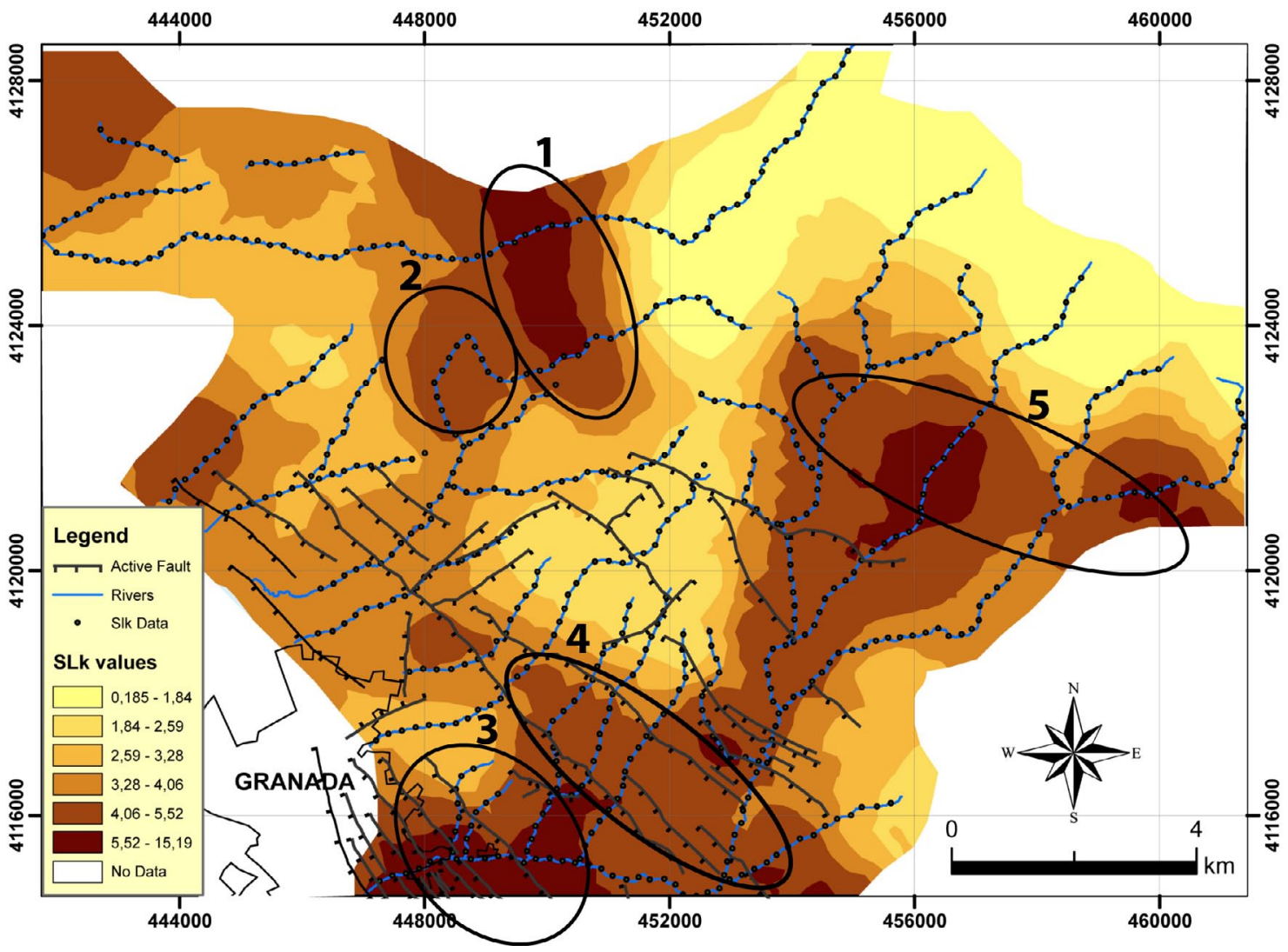

Fig. 4.- SLk map for the NE border of the Granada basin. The main anomalies are highlighted and numbered. Modified from Pérez-Peña et al. (2009c)

Fig. 4.- Mapa de SLk del borde NE de la Cuenca de Granada. Se resaltan y numeran las principales anomalías. Modificada de Pérez-Peña et al. (2009c)

verse fault (mountain fronts $\mathrm{Nc}, \mathrm{Nd}$ and $\mathrm{Ne}$ in figure 6, values are shown in table 1). Taking into account the integration between the $S_{m f}$ and the $V_{f}$ indices proposed by Silva et al. (2003) and the absence of geological marker useful to determine slip-rates, we are able to assign an uplift-rate ranging between 0.5 and $0.05 \mathrm{~m} / \mathrm{ky}$ for the southern hanging-wall block of this fault. In addition, the occurrence of the SLk anomaly 1 in figure 7 confirms such uplift.

The eastern part of the Sierra Alhamilla northern front shows low values of $S_{m f}$ and $V_{f}\left(V_{f}\right.$ in figure 6, values are shown in table 1 and 2, respectively) that allow us to assign an uplift rate higher than $0.5 \mathrm{~m} / \mathrm{ky}$ for the southern hanging-wall block of the north Alhamilla reverse faultsouth Gafarillo fault (NARF-SGF) system. This uplift is supported also by the high SLk anomaly 2 and 3 in figure 7 , which is located just to the south of this fault system, and by the southward basin asymmetries recognized here (Fig. 6). The occurrence of streams with convex longitudinal profiles and basins with convex and complex hypsometric curves in the northern slope support the Quaternary- to present-activity of this fault system (Fig. 7). The relative uplift of the southern block of the NARFSGF fault system changes local base-levels causing the occurrence of younger basins. In addition, in response to reverse displacement along this fault system, foot-reju-

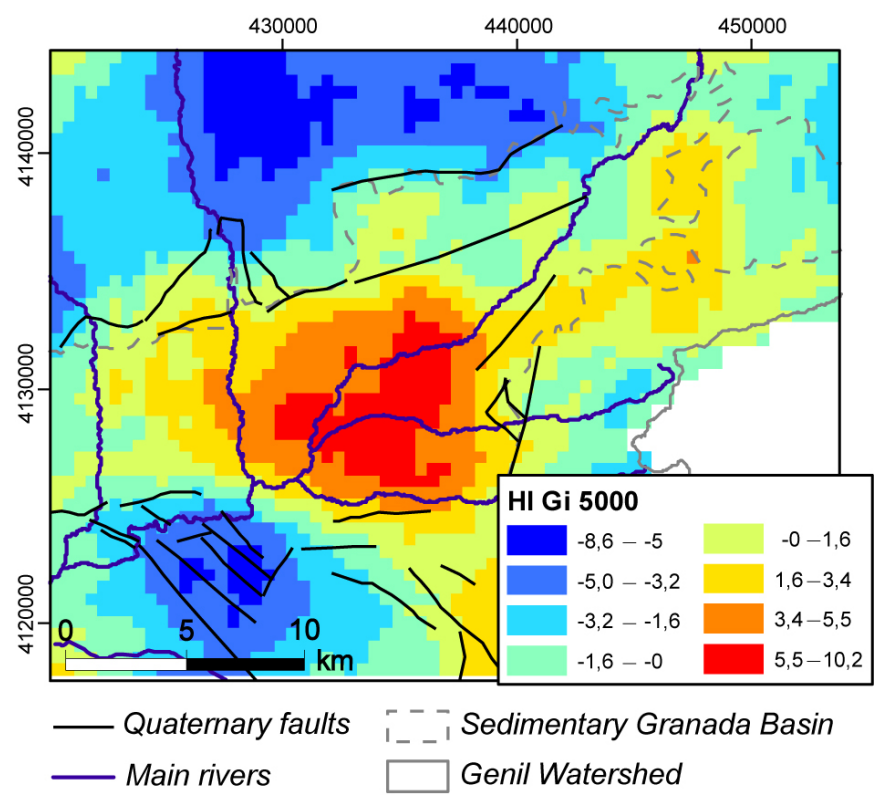

Fig. 5.- Getis-Ord*-statistic estimation for the HI value distribution in the NE border of the Granada basin. The figure shows how the clusters of high values are related with the footwall of active normal faults. . Modified from Pérez-Peña et al. (2009c)

Fig. 5.- Estimación estadística Getis-Ord* para la distribución de valores de la integral hipsométrica en el borde NE de la Cuenca de Granada. La figura muestra cómo las agrupaciones con altos valores de IH están relacionadas con los bloques de muro de las fallas normales. Modificada de Pérez-Peña et al. (2009c) 


\begin{tabular}{cccc} 
Front & Smf & Front & Smf \\
\hline $\mathrm{Sa}$ & 1.20 & $\mathrm{~W}$ & 1.06 \\
$\mathrm{Sb}$ & 1.30 & $\mathrm{Na}$ & 1.47 \\
$\mathrm{Sc}$ & 1.01 & $\mathrm{Nb}$ & 1.22 \\
$\mathrm{Sd}$ & 1.70 & $\mathrm{Nc}$ & 1.44 \\
$\mathrm{Se}$ & 1.14 & $\mathrm{Nd}$ & 1.40 \\
$\mathrm{Sf}$ & 1.96 & $\mathrm{Ne}$ & 1.23 \\
$\mathrm{Sg}$ & 1.01 & $\mathrm{Nf}$ & 1.10 \\
$\mathrm{Sh}$ & 1.30 & $\mathrm{E}$ & 1.38
\end{tabular}

Table 1.- Table reporting the $S_{m f}$ (mountain front sinuosity) values for each front shown in the map.

Tabla 1.- Valores del $S_{m f}$ (sinuosidad del frente montañoso) para cada uno de los frentes que se muestran en el mapa.

\begin{tabular}{cccc} 
Stream & Vf & Stream & Vf \\
\hline 1 & 0.59 & 22 & 0.92 \\
3 & 0.25 & 23 & 1.22 \\
4 & 0.90 & 24 & 1.22 \\
7 & 0.87 & 27 & 1.22 \\
9 & 0.34 & 29 & 1.44 \\
11 & 0.14 & 30 & 1.44 \\
12 & 0.46 & 32 & 1.40 \\
13 & 0.78 & 33 & 1.10 \\
14 & 1.08 & 34 & 1.10 \\
17 & 0.84 & 35 & 1.10 \\
20 & 0.27 & 36 & 1.38 \\
21 & 0.22 & 37 & 1.23 \\
\hline
\end{tabular}

Table 2.- Table reporting the $V f$ (valley floor width-to-height ratio) values for each stream shown in the map.

Tabla 2.- Valores del $V f$ (relación entre anchura-altura de los valles fluviales) para cada uno de los valles que se muestran en el mapa.

venation processes should occur in basins above the fault trace, thus generating complex hypsometric curve shapes.

\subsubsection{Geomorphic response to the Pliocene-Quaternary high-angle normal faulting}

The low $S_{m f}$ and $V_{f}$ values obtained for the Sierra Alhamilla southern front ( $\mathrm{Sa}, \mathrm{Sc}$ and $\mathrm{Se}$ in figure 6, values are shown in table 1) support the recent to present activity of the NW-SE- to NNW-SSE-striking high-angle normal fault system that affects the southern slope of the ridge and the Almería-Níjar basin. The integration of these two indices allows us to assign an uplift rate to these faults higher than $0.5 \mathrm{~m} / \mathrm{ky}$.

The Quaternary activity of this fault system is confirmed by the occurrence of basins with S-shaped, convex and complex hypsometric curve shapes at the southern slope (Fig. 6). In response to NE-SW normal displacement, the relative uplift of southern slope sectors with respect to the sedimentary basin has changed the streams local base-level thus, producing younger drainage basins or head-rejuvenation processes that generate complex hypsometric curve shapes (Fig. 6). According to these observations, longitudinal stream profiles in the southern slope locally show concave-convex profiles with knickpoints and high SLk anomalies 4, 5 and 6 occur (Fig. 7). An analogous scenario can be described for the eastern part of the Sierra Alhamilla southern slope where a Pliocene-Quaternary high-angle normal fault having a $\mathrm{N}-\mathrm{S}$ strike and an eastwards normal displacement occurs. This fault producing a relative uplift of its western footwall block causes the occurrence of low $S_{m f}$ and $V_{f}$ values, basins with complex hypsometric curve and the high SLk anomaly 7 shown in figure 7 .

\section{Discussion}

\subsection{New tectonic model for the Sierra Nevada area}

The geomorphic indexes for the Sierra Nevada suggest that the more recent uplift is concentrated along its western mountain front, where $S_{m f}$ and $V_{f}$ present the lowest values. Higher incision rates in this western sector can be due to tectonic uplift in the hanging wall of the NW-SE normal faults. These normal faults belong to the same system as the one in the NE border of the Granada basin. The N-S variations in the geomorphic indices are caused by the differences in the base level for the river incision that, in turn, are due to a differential uplift of both mountain fronts. The southern front of the Sierra Nevada has been interpreted as a transfer fault that links two areas of active extension (the Granada-Padul basins, and the western Sierra de Gador) (Fig. 8; Martínez-Martinez et al., 2006; Pérez-Peña et al., 2010). The northern mountain front of Sierra Nevada corresponds to an unconformity between the Neogene-Quaternary sedimentary infill of the Guadix-Baza basin and the metamorphic rocks of Sierra Nevada. This mountain front and the Neogene Guadix-Baza basin are located in the foot wall of the mentioned system.

The Quaternary landscape evolution of the Granada and Guadix-Baza basins are very different, and are strongly conditioned by tectonics. The Granada basin has a mean altitude of $600 \mathrm{~m}$, being scarcely incised by the fluvial network, except in the NE margins of the basin near the fault-bounded mountain front. The Guadix-Baza basin has a mean altitude of $1000 \mathrm{~m}$, with the fluvial network deeply incised (down to $200 \mathrm{~m}$ ) into the Neogene-Quaternary infill. These topographic and geomorphic differences are probably due to the different tectonic location of the two basins: The Granada basin, except its NE border, is located in the hanging wall of the NW-SE extensional system bounding Sierra Nevada to the west, being thus subjected in a great extent to Quater- 


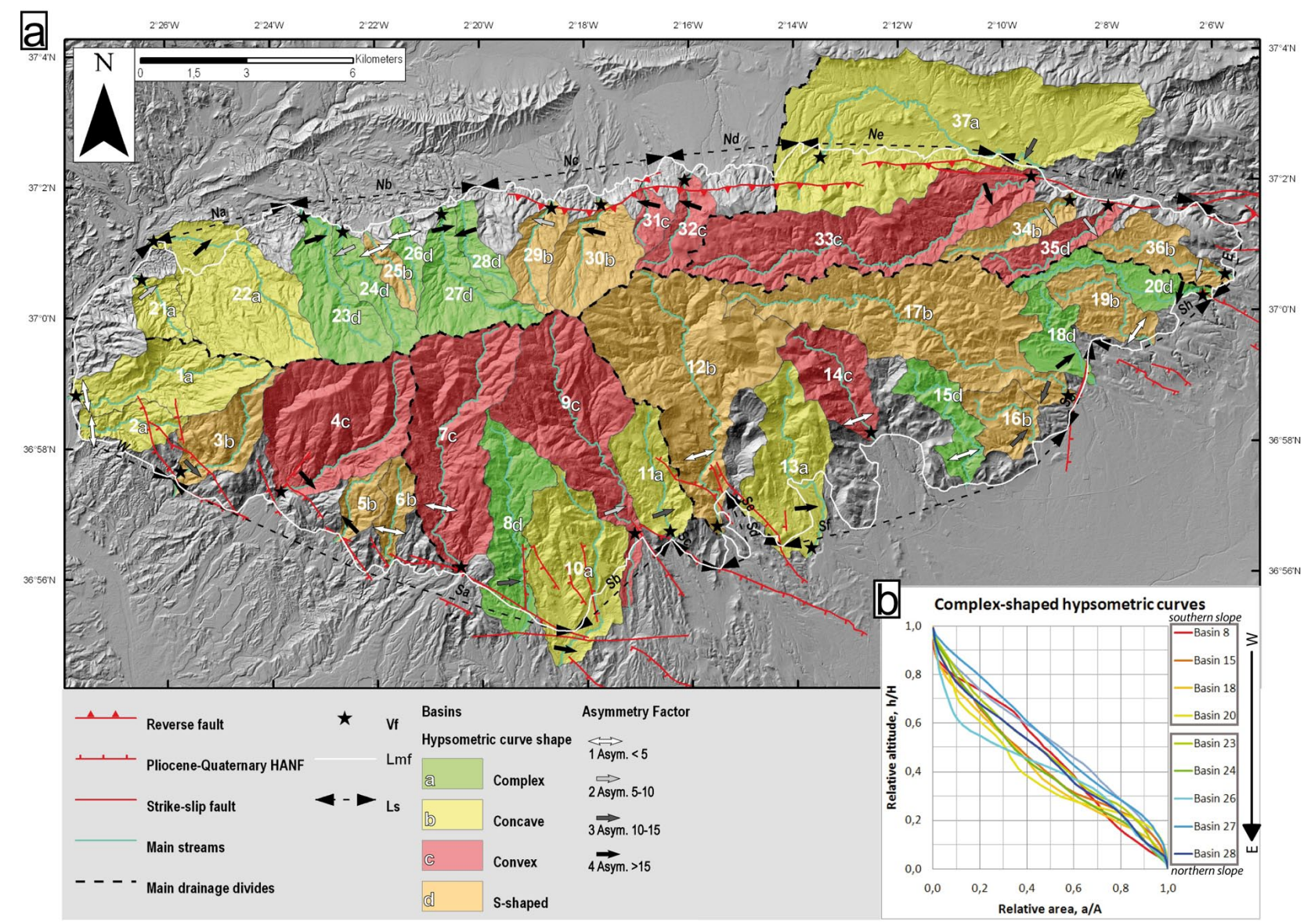

Fig. 6.- a) Drainage basin distribution map where the main drainage divides, streams, watersheds of main streams and drainage basins (classified depending on their hypsometric curve shapes) and Quaternary active tectonics (after Martínez-Martínez et al., 1997) are shown. The following geomorphic indices are reported: the basin asymmetry factor, the mountain front sinuosity $\left(S_{m f}\right.$, together with the mountain front, $L_{m f}$, and its length measured along a straight line, $\left.L_{S}\right)$, and finally the valley floor width-to-height ratio $\left(V_{f}\right)$. b) Complex hypsometric curves associated with "rejuvenation" processes, at the foot or head of the streams.

Fig. 6.- a) Distribución de la red de drenaje, subcuencas y principales cauces fluviales (clasificados en función de la forma de su curva hipsométrica) y su relación con la tectónica activa cuaternaria en la Sierra Alhamilla (Martínez-Martínez et al., 1997). Se muestran los valores de los siguientes índices geomorfológicos: factor de asimetría de las subcuencas, sinuosidad de los frentes montañosos $\left(S_{m f}\right)$ y, finalmente, la relación entre anchura y altura de los valles fluviales $\left(V_{f}\right)$. b) Curvas hipsométricas complejas asociadas con los procesos de "rejuvenecimiento" en los pies o cabeceras de los valles fluviales.

nary subsidence. On the contrary, the Guadix-Baza basin is located in the footwall of the above-mentioned extensional system, being part together with Sierra Nevada of a single block affected by tectonic uplift during the Quaternary (Fig. 8).

Traditional tectonic models of the Sierra Nevada area do not mention the important differences between the eastern and western part of the range or between its northern and southern mountain fronts (Galindo-Zaldívar et al., 2003). Some authors have proposed recent models for this area (Martínez-Martínez et al., 2004, 2006) explaining the mentioned differences within the mountain range, but they still do not explain the significant contrast between the landscapes of the Granada and Guadix-Baza basins. The evolution of these two basins has traditionally considered very similar (Fernández et al., 1996; Rodríguez-Fernández and Sanz de Galdeano, 2006), with the only difference of the normal faulting affecting mainly to the Granada basin (Sanz de Galdeano et al., 2003; Azañón et al., 2004). Despite the fact that the Granada and Guadix-Baza basins present a similar evolution from Tortonian to Middle-Pleistocene, their Quaternary landscape evolution is rather different. The activity of the NW-SE normal faults in the Granada ba$\sin$ is not enough to explain the contrast in landscape, geomorphology, and drainage network incision respect to the Guadix-Baza basin. However, the tectonic model, based on Martínez-Martínez et al. (2006), is compatible with the results obtained through the combination of geomorphic analyses. They are part of the same extensional system causing extension in the Granada basin and the western part of Sierra de Gador. This exten- 


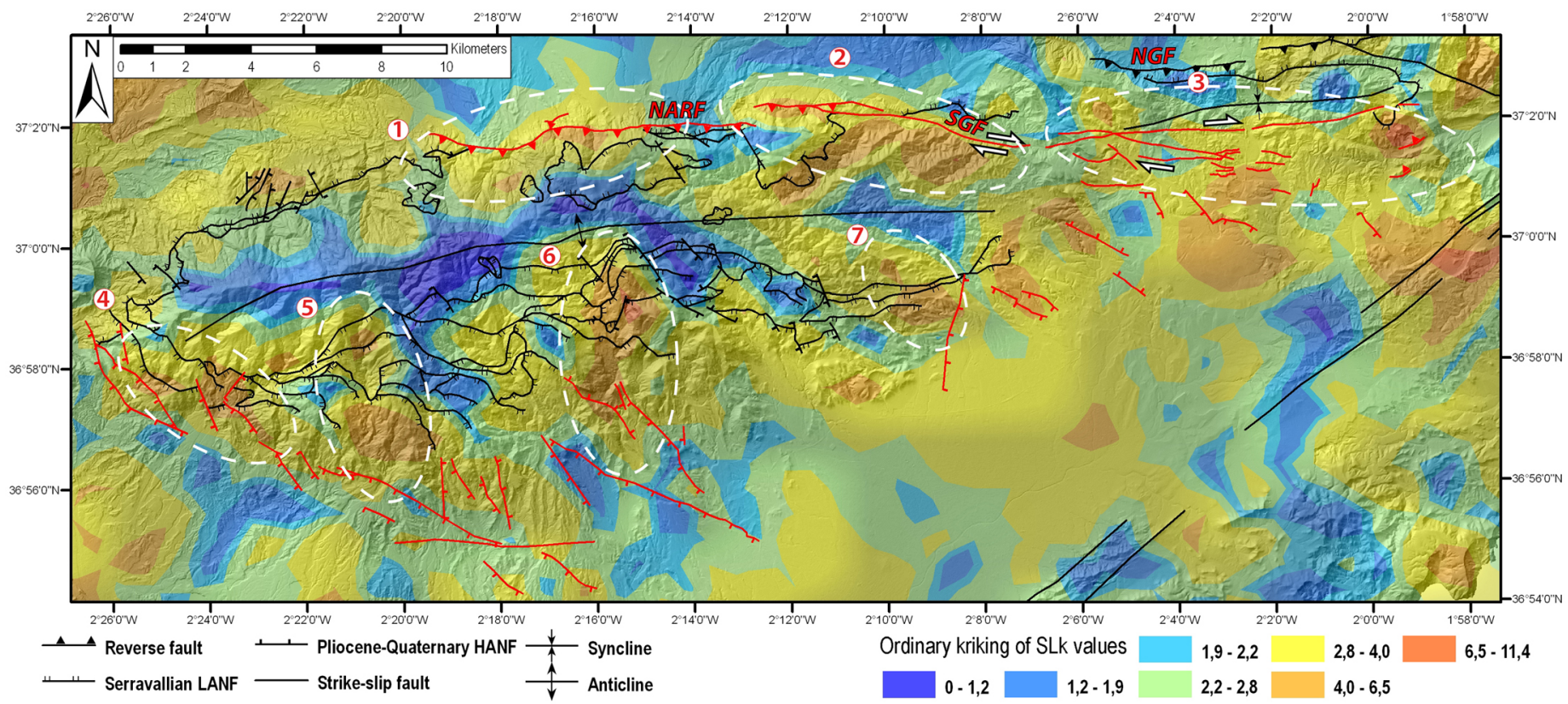

Fig. 7.- SLk map and main tectonic structures of Sierra Alhamilla: the North Alhamilla Reverse Fault (NARF) and the South Gafarillos Fault (SGF) after Martínez-Martínez et al.(1997). Active faults during the Quaternary are shown in red.

Fig. 7.- Mapa SLk y principales estructuras tectónicas de la Sierra Alhamilla: la falla inversa del N de Alhamilla (NARF) y la falla del Sur de Gafarillos (SGF) según Martínez-Martínez et al. (1997). Se muestran en rojo las fallas con actividad cuaternaria.

sional system, connected by a transfer zone to the south of Sierra Nevada, and the active NE-SW active folding in Sierra Nevada are compatible with the present-day NW-SE trend in the regional compressional stress. This model can help to elucidate the recent tectonic evolution of the whole system including Sierra Nevada mountain range and the Granada and Guadix-Baza Neogene basins. Uplift in the Sierra Nevada mountain range and the Guadix-Baza basin is a coetaneous process to the active extensional subsidence in the Granada basin.

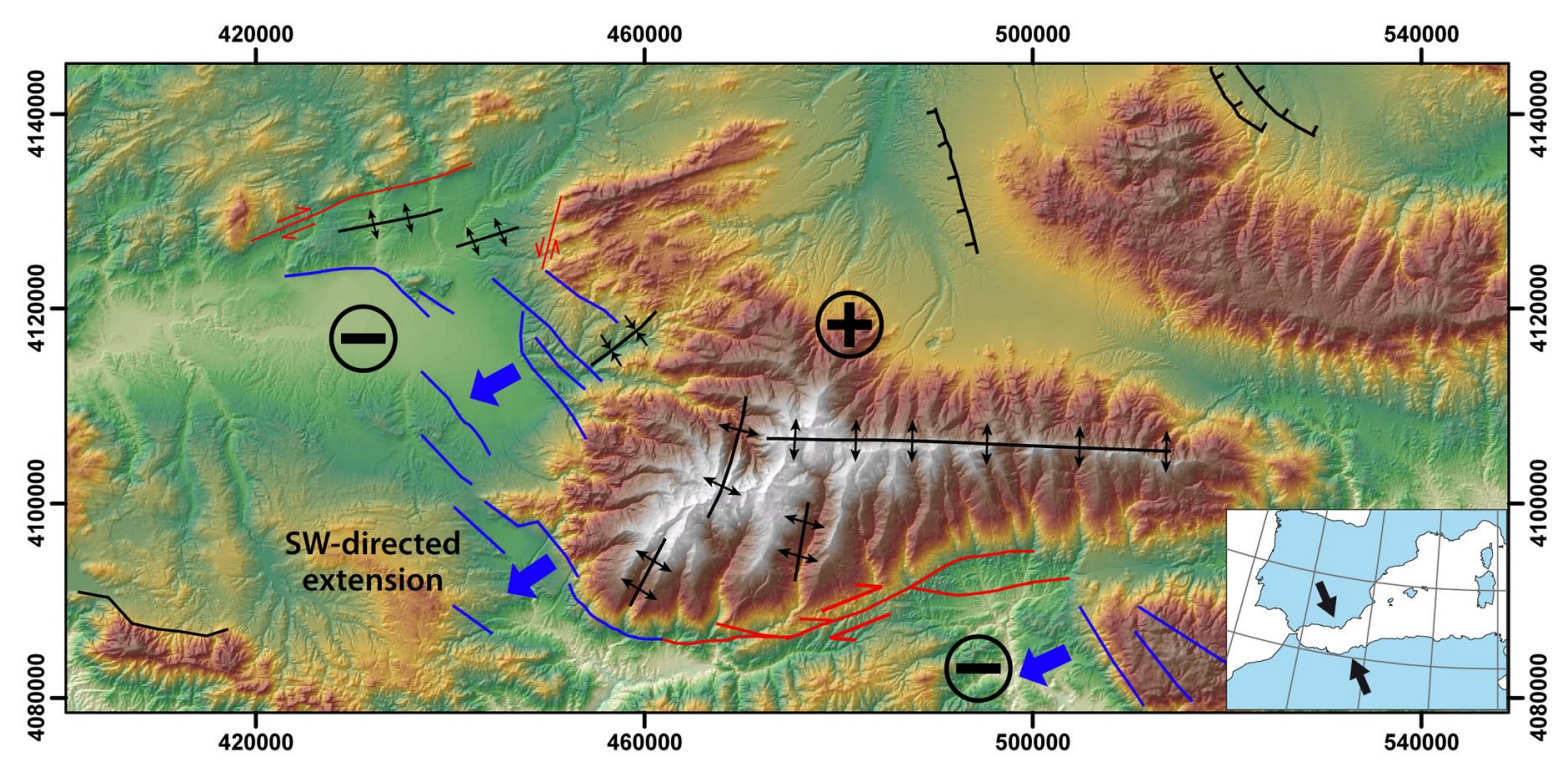

Fig. 8.- General sketch showing the tectonic configuration of the Sierra Nevada area. The uplifted block is located eastwards and it includes the Sierra Nevada mountain range, the Guadix-Baza basin and the NE border of the Granada basin. The Granada basin lies on the hanging wall of the extensional system, thus being affected by active sinking.

Fig. 8.- Esquema general que muestra la configuración tectónica del área de Sierra Nevada. El bloque levantado se sitúa hacia el este e incluye a Sierra Nevada, la Cuenca de Guadix-Baza y el borde NE de la Cuenca de Granada. La Cuenca de Granada está en el bloque de techo de un sistema extensional activo que produce su subsidencia. 


\subsection{Morphometric contribution to the tectonic scenario in the Sierra Alhamilla}

The qualitative and quantitative geomorphic analyses carried out in Sierra Alhamilla suggest that it has been tectonically active during the Pleistocene and the Holocene, and probably up to present-day. The tectonic structures that control the hillslope and drainage network of the Sierra Alhamilla and surrounding Neogene to Quaternary sedimentary basins are the Polopos fault system and the NW-SE- to NNW-SSE-striking high-angle normal fault system, to the north and to the south of the ridge, respectively. In both cases the relative uplift of one of the two fault blocks (the foot-wall in the case of the normal faults and the hanging-wall in that of the reverse faults) induces a set of geomorphic responses. Typically they are: regular mountain fronts that show low values of $S_{m f}$ and $V_{f}$, highly asymmetric drainage basins that give information about tectonic tilting, streams with convex longitudinal profiles and drainage basins with convex and complex hypsometric curves in response to head- or foot-rejuvenation processes, and finally high Slk anomalies near to the fault and on the uplifted fault block.

\section{Conclusion}

This work summarizes some of the new GIS-based methods for the landscape analysis recently used in two areas of the Betic Cordillera (central and eastern sectors). Through the application of such geomorphic analyses it is possible to understand tectonic activity and Quaternary landscape evolution, both necessary to establish coherent tectonic models. In the Betic Cordillera, the present-day landscape is mainly conditioned by the recent tectonic activity, and has to be considered as the key to estimate differential uplift, folding, subsidence and displacement rates.

Through the application of new GIS-based methodologies for drainage network and landscape analysis it is possible to reach a better understanding of the recent tectonic activity. These morphometric analyses are especially valuable in areas of low-to-medium tectonic rates $(0.1-2 \mathrm{~mm} / \mathrm{yr})$ with scarce chronological dating. In this work, on the basis of these morphometric analyses, new and more complete tectonic models have been proposed for Sierra Nevada and Sierra Alhamilla regions (central and eastern Betic Cordillera respectively). The evolution of Sierra Nevada mountain range is closely related with the landscape of the Granada and Guadix-Baza basins. The Granada basin is located in the hanging wall of a NW-SE directed extensional system, whereas the Guadix-Baza basin, the NE border of the Granada basin, and the Sierra Nevada mountain range are located in the footwall, thus being affected by active uplift in the Upper-Pleistocene. In the Sierra Alhamilla area, the use of geomorphic analyses allow estimating tectonic activity and infer tectonic rates for structures that were thought to be inactive in the Upper-Pleistocene.

\section{Acknowledgments}

This study was supported by research projects CGL2008-03249/BTE, CGL-2011-29920, TOPOIBERIA CONSOLIDER-INGENIO2010 and CTM200766179-C02-01/MAR from the Spanish Ministry of Science and Innovation and MMA083/2007 from the Spanish Ministry of Environment. We thank Dr. José A. Álvarez and an anonymous reviewer for their constructive revisions that helped to improve the scientific quality of this paper.

\section{References}

Alfaro, P., Galindo Zaldívar, J., Jabaloy Sánchez, A., López Garrido, A.C., Sanz de Galdeano, C. (2001): Evidence for the activity and paleoseismicity of the Padul fault (Betic Cordillera, SE Spain). Acta Geológica Hispánica 36, 283-295.

Alfaro, P., Delgado, J., Sanz de Galdeano, C., Galindo-Zaldívar, J., García-Tortosa, F.J., López-Garrido, A.C., López-Casado, C., Marín-Lechado, C., Gil, A., Borque, M.J. (2008): The Baza Fault: a major active extensional fault in the central Betic Cordillera (south Spain). International Journal of Earth Sciences (Geol Rundsch) 97, 1353-1365. doi:10.1007/s00531-007-0213-z.

Azañón, J. M., Azor, A., Booth-Rea, G., Torcal, F. (2004): Small-scale faulting, topographic steps and seismic ruptures in the Alhambra (Granada, southeast Spain), Journal of Quaternary Science 19, 219227. doi: $10.1002 /$ jqs. 838.

Azañón, J.M., Azor, A., Pérez-Peña, J.V., Carrillo, J.M. (2005): Late Quaternary large-scale rotational slides induced by river incision: The Arroyo de Gor area (Guadix basin, SE Spain). Geomorphology 69, 152-168. doi:10.1016/j.geomorph.2004.12.007.

Balanyá, J.C., García-Dueñas, V. (1987): Les directions structurales dans le Domaine d'Alborán de part et d'autre du Détroit de Gibraltar. Comptes Rendus de l'Académie des Sciences de Paris 304, 929-932.

Barragán, G. (1997): Evolución Geodinámica de la Depresión de Vera. PhD Thesis, Universidad de Granada: 300 p.

Bell, J.W., Amelung, F., King, G.C.P. (1997): Preliminary late Quaternary slip history of the Carboneras fault, southeastern Spain. Journal of Geodynamics 24, 51-66. doi:10.1016/S0264-3707(96)00029-4.

Booth-Rea, G., Azañón, J.M., Azor, A., García-Dueñas, V. (2004): Influence of strike-slip fault segmentation on drainage evolution and topography. A case study: the Palomares fault zone (southeastern Betics, Spain). Journal of Structural Geology 26, 1615-1632. doi:10.1016/j.jsg.2004.01.007.

Booth-Rea, G., Azañón, J.M., Martínez-Martínez, J.M., Vidal, O., García-Dueñas, V. (2005): Contrasting structural and P-T evolutions of tectonic units in the southeastern Betics: key for understanding the exhumation of the Alboran Domain HP/LT crustal rocks (Western Mediterranean). Tectonics 24, TC2009. doi:10.1029/2004TC001640. 
Booth-Rea, G., Ranero, C., Martínez-Martínez, J.M., Grevemeyer, I. (2007): Crustal types and Tertiary tectonic evolution of the Alborán sea, western Mediterranean. Geochemistry Geophysics Geosystems 8, Q10004. doi:10.1029/2007GC001639.

Bousquet, J.C. (1979): Quaternary strike-slip faults in southeastern Spain. Tectonophysics 52, 277-286. doi:10.1016/00401951(79)90232-4.

Bull, W.B. (1977): Tectonic geomorphology of the Mojave Desert, California. U.S. Geological Survey Contract Report 14-08-001-G394, 376 p.

Bull, W.B. (2007): Tectonic Geomorphology of Mountains: A New Approach to Paleoseismology. Wiley-Blackwell, Oxford: 326 p.

Bull, W.B. (2009): Tectonically Active Landscapes. Wiley-Blackwell, Oxford: $326 \mathrm{p}$.

Bull, W.B., McFadden, L.D. (1977): Tectonic geomorphology north and south of the Garlock fault, California. In: D. O. Doehering (ed.), Geomorphology in arid regions. Proccedings at the Eighth Annual Geomorphology Simposium. State University of New York. Binghamton, NY: 115-138.

Burbank, D.W., Anderson, R.S. (2001): Tectonic Geomorphology. Blackwell Science, Oxford: 247 p.

Calvache, M.L., Viseras, C. (1997): Long-term control mechanisms of stream piracy processes in Southeast Spain. Earth Surface Processes and Landforms 22, 93-105. doi:10.1002/(SICI)1096-9837(199702).

Clark, M.K., Schoenbohm, L.M., Royden, L.H., Whipple, K.X., Burchfiel, B.C., Zhang, X., Tang, W., Wang, E., Chen, L. (2004): Surface uplift, tectonics, and erosion of eastern Tibet from large-scale drainage patterns. Tectonics 23, TC1006. doi:10.1029/2002TC001402.

Comas, M.C., Platt, J.P., Soto, J.I., Watts, A.B. (1999): The Origin and Tectonic History of the Alborán Basin: Insights from Leg 161 Results. In: R. Zahan, M. C. Comas, A. Klaus (eds.), Proceedings of the Ocean Drilling Program, Scientific Results: 555-579.

Dewey, J.F., Helman, M.L., Turco, E., Hutton, D.H.W., Knott, S.D. (1989): Kinematics of the western Mediterranean. In: M. P. Coward, D. Dietrich , R. G. Park (ed.), Alpine Tectonics. Special Publication Geological Society of London. London: 265-283. doi:10.1144/ GSL.SP.1989.045.01.15.

El Hamdouni, R., Irigaray, C., Fernandez, T., Chacon, J., Keller, E.A. (2008): Assessment of relative active tectonics, southwest border of the Sierra Nevada (southern Spain). Geomorphology 96, 150-173. doi:10.1016/j.geomorph.2007.08.004.

Fernández, J., Viseras, C., Soria, J. (1996): Stratigraphic architecture of the Neogene basins in the central sector of the Betic Cordillera (Spain): tectonic control and base-level changes. In: Friend, P.F., Dabrio, C. (eds.), Tertiary Basins of Spain: The Stratigraphic Record of Crustal Kinematics. Cambridge Univ. Press, Cambridge: 353-365.

Galindo-Zaldívar, J., Gil, A.J., Borque, M.J., González Lodeiro, F., Jabaloy Sánchez, A., Marín-Lechado, C., Ruano, P., Sanz de Galdeano, C. (2003): Active faulting in the internal zones of the central Betic Cordilleras (SE, Spain). Journal of Geodinamics 36, 239-250. doi:10.1016/S0264-3707(03)00049-8.

García-Dueñas, V., Balanyá, J.C., Martínez-Martínez, J.M. (1992): Miocene extensional detachments in the outcropping basement of the Northern Alboran Basin (Betics) and their tectonic implications. Geo-Marine Letters 12, 88-95. doi:10.1007/BF02084917.

García-Tortosa, F.J., Alfaro, P., Galindo-Zaldívar, J., Gibert, L., López-Garrido, A.C., Sanz de Galdeano, C., Ureña, M. (2008): Geomorphologic evidence of the active Baza Fault (Betic Cordillera, South Spain). Geomorphology 97, 374-391. doi:10.1016/j. geomorph.2007.08.007.

García-Tortosa, F.J., Alfaro, P., Sanz de Galdeano, C., Galindo-Zaldívar, J. (2011). Glacis geometry as a geomorphic marker of recent tectonics: The Guadix-Baza basin (South Spain). Geomorphology 125, 517-529. doi:10.1016/j.geomorph.2010.10.021.

Gràcia, E., Pallas, R., Soto, J.I., Comas, M., Moreno, X., Masana, E., Santanach, P., Diez, S., Garcia, M., Danobeitia, J. (2006): Active faulting offshore SE Spain (Alboran Sea): Implications for earthquake hazard assessment in the Southern Iberian Margin. Earth and Planetary Science Letters 241, 734-749. doi:10.1016/j. eps1.2005.11.009.

Giaconia, F., Booth-Rea, G., Martínez-Martínez, J.M., Azañón, J.M., Pérez-Peña, J.V., Pérez-Romero, J., Villegas I. (2012): Geomorphologic evidence of active tectonics in Sierra Alhamilla (eastern Betics, SE Spain). Geomorphology 145-146, 90-106. doi:10.1016/j. geomorph.2011.12.043.

Hack, J.T. (1973): Stream profile analysis and stream-gradient index. Journal of Research of the U.S. Geological Survey 1, 421-429.

Huibregtse, P., van Alebeek, H., Zall, M., Biermann, C. (1998): Paleostress analysis of the northern Nijar and southern Vera basins: constraints for the Neogene displacement history of major strikeslip faults in the Betic Cordilleras, SE Spain. Tectonophysics 300, 79-101. doi:10.1016/S0040-1951(98)00235-2.

Jonk, R., Biermann, C. (2002): Deformation in Neogene sediments of the Sorbas and Vera Basins (SE Spain): constraints on simple-shear deformation and rigid body rotation along major strike-slip faults. Journal of Structural Geology 24, 963-977. doi:10.1016/S01918141(01)00107-9.

Keller, E.A., Pinter, N. (2002): Active Tectonics. Earthquakes, Uplift, and Landscape. Prentice Hall, New Jersey: 362 p.

Keller, E.A., Sanz de Galdeano, C., Chacon, J. (1996): Tectonic geomorphology and earthquake hazard of Sierra Nevada, Southern Spain. $1^{a}$ Conferencia Internacional Sierra Nevada, Granada, 201218.

Korup, O. (2006): Rock-slope failure and the river long profile. Geo$\log y$ 34, 45-48. doi:10.1130/G21959.1.

Marín-Lechado, C., Galindo-Zaldivar, J., Rodriguez-Fernandez, L.R., Serrano, I., Pedrera, A. (2005): Active faults, seismicity and stresses in an internal boundary of a tectonic arc (Campo de Dalias and Nijar, southeastern Betic Cordilleras, Spain). Tectonophysics 396, 81-96. doi:10.1016/j.tecto.2004.11.001.

Martínez-Díaz, J.J. (2002): Stress field variation related to fault interaction in a reverse oblique-slip fault: the Alhama de Murcia fault, Betic Cordillera, Spain. Tectonophysics 356, 291-305. doi:10.1016/ S0040-1951(02)00400-6.

Martínez-Martínez, J.M., Azañón, J.M. (1997): Mode of extensional tectonics in the southeastern Betics (SE Spain). Implications for the tectonic evolution of the peri-Alborán orogenic system. Tectonics 16, 205-225. doi:10.1029/97TC00157.

Martínez-Martínez, J.M., Soto, J.I., Balanyá, J.C. (2002): Orthogonal folding of extensional detachments: structure and origin of the Sierra Nevada elongated dome (Betics, SE Spain). Tectonics 21, 1012. doi:10.1029/2001TC001283.

Martínez-Martínez, J.M., Soto, J.I., Balanyá, J.C. (2004): Elongated domes in extended orogens: A mode of mountain uplift in the Betics (southeast Spain). In: D. L. Whitney, C. Teyssier, C. S. Siddoway (ed.), Gneiss domes in orogeny. Geological Society of America. Boulder, Colorado: 243-266.

Martínez-Martínez, J.M., Booth-Rea, G., Azañón, J.M., Torcal, F. (2006): Active transfer fault zone linking a segmented extensional system (Betics, southern Spain): Insight into heterogeneous extension driven by edge delamination. Tectonophysics 422, 159-173. doi:10.1016/j.tecto.2006.06.001.

Martín-Rojas, I., Martín-Martín, M., Sanz de Galdeano, C. (2001): Índices geomorfológicos de los frentes montañosos del borde occidental de Sierra Nevada (Granada - España). In: C. Sanz de Galdea- 
no, J. Pelaez Montilla, A. C. López Garrido (eds.), La cuenca de Granada. Estructura, tectónica activa, sismicidad, geomorfología y dataciones existentes. Universidad de Granada, Granada: 59-66.

Masana, E., Martínez-Díaz, J.J., Hernández-Enrile, J.L., Santanach, P. (2004): The Alhama de Murcia fault (SE Spain), a seismogenic fault in a diffuse plate boundary: Seismotectonic implications for the Ibero-Magrebian region. Journal of Geophysical Research 109, B01301. doi:10.1029/2002JB002359.

McClusky, S., Reilinger, R., Mahmoud, S., Ben Sari, D., Tealeb, A. (2003): GPS constraints on Africa (Nubia) and Arabia plate motions. Geophysical Journal International 155, 126-138. doi:10.1046/ j.1365-246X.2003.02023.x.

Menéndez, I., Silva, P.G., Martín-Betancor, M., Pérez-Torrado, F.J., Guillou, H., Scaillet, S. (2008). Fluvial dissection, isostatic uplift, and geomorphological evolution of volcanic islands (Gran Canaria, Canary Islands, Spain). Geomorphology 102, 189-203. doi:10.1016/j.geomorph.2007.06.022.

Montenat, C., Ott d'Estevou, P. (1990): Easten betic Neogene BasinsA review. In: C. Montenat (ed.), Les Bassins Neogenes du Domaine Bétique Orientale (Espagne). Documents et Travaux IGAL, 9-15.

Moran, P.A.P. (1950): Notes on continuous stochastic phenomena. Biometrika 37(1-2), 17-23.

Ott d'Estevou, P., Montenant, C. (1990): Le Bassin de Sorbas-Tabernas. In: C. Montenant (ed.), Les Bassins Neogenes du Domaine Bétique Oriental (Espagne). IGAL, CNRS. Paris: 101-128.

Ord, J. K., Getis, A. (1995): Local spatial autocorreltacion statistics. Distributional issues and application. Geographical analysis 27, 286-306. doi:10.1111/j.1538-4632.1995.tb00912.x.

Ouchi, S. (1985): Response of alluvial rivers to slow active tectonic movement. Geological Society of America Bulletin 96, 504-515. doi:10.1130/0016-7606(1985)96<504:ROARTS>2.0.CO;2.

Pedrera, A., Marin-Lechado, C., Galindo-Zaldivar, J., Rodriguez-Fernandez, L.R., Ruiz-Constan, A. (2006): Fault and fold interaction during the development of the Neogene-Quaternary Almeria-Nijar basin (SE Betic Cordilleras). In: C. Moratti, A. Chaluan (eds.), Tectonics of the Western Mediterranean and North Africa. Geological Society, London, Special Publications, 217-230. doi:10.1144/GSL. SP.2006.262.01.13.

Pedrera, A., Pérez-Peña, J.V., Galindo-Zaldívar, J., Azañón, J.M., Azor, A. (2009): Testing the sensitivity of geomorphic indices in areas of low-rate active folding (eastern Betic Cordillera, Spain). Geomorphology 105, 218-231. doi:10.1016/j.geomorph.2008.09.026.

Pérez-Peña, J.V., Azañón, J.M., Azor, A., Delgado, J., González-Lodeiro, F. (2009a): Spatial analysis of stream power using GIS: SLk anomaly maps. Earth Surface Processes and Landforms 34, 16-25. doi:10.1002/esp.1684.

Pérez-Peña, J.V., Azañón, J.M., Azor, A. (2009b): CalHypso: An ArcGIS extension to calculate hypsometric curves and their statistical moments. Applications to drainage basin analysis in SE Spain. Computers \& Geosciences 35, 1214-1223. doi:10.1016/j. cageo.2008.06.006.

Pérez-Peña, J.V., Azañón, J.M., Booth-Rea, G., Azor, A., Delgado, J. (2009c): Differentiating geology and tectonics using a spatial autocorrelation technique for the hypsometric integral. Journal of Geophysical Research-Earth Surface 114, F02018. doi:10.1029/2008JF001092.

Pérez-Peña, J.V., Azañón, J.M., Azor, A., Tuccimei, P., Della Seta, M., Soligo, M. (2009d): Quaternary landscape evolution and erosion rates for an intramontane Neogene basin (Guadix-Baza basin, SE Spain). Geomorphology 106, 206-218. doi:10.1016/j.geomorph.2008.10.018.

Pérez-Peña, J.V., Azor, A., Azañón, J.M., Keller, E.A. (2010): Active tectonics in the Sierra Nevada (Betic Cordillera, SE Spain): Insights from geomorphic indexes and drainage pattern analysis. Geomorphology 119, 74-87. doi:10.1016/j.geomorph.2010.02.020.

Platt, J.P., Allerton, S., Kirker, A., Mandeville, C., Mayfield, A., Platzman, E.S., Rimi, A. (2003): The ultimate arc: Differential displacement, oroclinal bending, and vertical axis rotation in the External Betic-Rif arc. Tectonics 22, 1017. doi:10.1029/2001TC001321.

Reinhardt, L.J., Bishop, P., Hoey, T.B., Dempster, T.J., Sanderson, D.C.W. (2007): Quantification of the transient response to baselevel fall in a small mountain catchment: Sierra Nevada, southern Spain. Journal of Geophysical Research-Earth Surface 112, F03S05. doi:10.1029/2006JF000524.

Rodríguez-Fernández, J., Sanz de Galdeano, C. (2006): Late orogenic intramontane basin development: the Granada basin, Betics (southern Spain). Basin Research 18, 85-102. doi:10.1111/j.13652117.2006.00284.x.

Rodríguez-Fernández, J., Azor, A., Azañón, J.M. (2012): The Betic intramontane basins (SE spain): stratigraphy, subsidence, and tectonic history. In: Busby, C., Azor, A. (eds.), Tectonics of Sedimentary Basins: Recent Advances, Blackwell Publishing Ltd, 23, 461-479.

Sanz de Galdeano, C. (1996): Datos sobre las deformaciones neógenas y cuaternarias del sector del Padul (Granada). $1^{a}$ Conferencia Internacional Sierra Nevada, Granada, 219-231.

Sanz de Galdeano, C., Peláez-Montilla, J.A., Casado C.L. (2003): Seismic potential of the main active faults in the Granada basin (southern Spain), Pure and Applied Geophysics 160, 1537-1556. doi:10.1007/s00024-003-2359-3.

Sanz de Galdeano, C., Shanov, S., Galindo-Zaldivar, J., Radulov, A., Nikolov, G. (2010): A new tectonic discontinuity in the Betic Cordillera deduced from active tectonics and seismicity in the Tabernas Basin. Journal of Geodynamics 50, 57-66. doi:10.1016/j. jog.2010.02.005.

Schumm, S.A., Dumont, J.F., Holbrook, J.M. (2000): Active tectonics and alluvial rivers. Cambridge University Press, Cambridge: $276 \mathrm{p}$.

Serpelloni, E., Vannucci, G., Pondrelli, S., Argnani, A., Casula, G., Anzidei, M., Baldi, P., Gasperini, P. (2007): Kinematics of the Western Africa-Eurasia plate boundary from focal mechanisms and GPS data. Geophysical Journal International 169, 1180-1200. doi:10.1111/j.1365-246X.2007.03367.x.

Silva, P.G., Goy, J.L., Zazo, C., Bardají, T. (2003): Fault-generated mountain fronts in southeast Spain: geomorphologic assessment of tectonic and seismic activity. Geomorphology 50, 203-225. doi:10.1016/S0169-555X(02)00215-5.

Stapel, G., Moeys, R., Biermann, C. (1996): Neogene evolution of the Sorbas basin (SE Spain) determined by paleostress analysis. Tectonophysics 255, 291-305. doi:10.1016/0040-1951(95)00190-5.

Strahler, A.N. (1952): Hypsometric (area-altitude) analysis of erosional tophography. Geological Society of America Bulletin 63, $1117-$ 1142. doi:10.1130/0016-7606(1952)63[1117:HAAOET]2.0.CO;2.

Vázquez, M., Jabaloy, A., Barbero, L., Stuart, F. (2011): Deciphering tectonic- and erosion-driven exhumation of the Nevado-Filábride Complex (Betic Cordillera, Southern Spain) by low temperature thermochronology. Terra Nova, 23, 257-263. doi:10.1111/j.13653121.2011.01007.x.

Weijermars, R., Roep, T.B., Van den Eeckhout, B., Postma, G., Kleverlaan, K. (1985): Uplift history of a Betic fold nappe inferred from Neogene-Quaternary sedimentation and tectonics (in the Sierra Alhamilla and Almería, Sorbas and Tabernas Basins of the Betic Cordilleras, SE Spain). Geologie en Mijnbouw 64, 397-411.

Whipple, K.X., Tucker, G.E. (1999): Dynamics of the stream-power river incision model: Implications for height limits of mountain ranges, landscape response timescales, and research needs. Journal of Geophysical Research-Solid Earth 104, 17661-17674. doi:10.1029/1999JB900120. 